\title{
A novel delta current method for transport stoichiometry estimation
}

Xuesi M Shao ${ }^{2^{*}}$, Liyo Kao ${ }^{1}$ and Ira Kurtz ${ }^{1,3}$

\begin{abstract}
Background: The ion transport stoichiometry (q) of electrogenic transporters is an important determinant of their function. $q$ can be determined by the reversal potential $\left(E_{\text {rev }}\right)$ if the transporter under study is the only electrogenic transport mechanism or a specific inhibitor is available. An alternative approach is to calculate delta reversal potential $\left(\Delta \mathrm{E}_{\text {rev }}\right)$ by altering the concentrations of the transported substrates. This approach is based on the hypothesis that the contributions of other channels and transporters on the membrane to $E_{\text {rev }}$ are additive. However, $E_{\text {rev }}$ is a complicated function of the sum of different conductances rather than being additive.

Results: We propose a new delta current $(\Delta I)$ method based on a simplified model for electrogenic secondary active transport by Heinz (Electrical Potentials in Biological Membrane Transport, 1981). $\Delta l$ is the difference between two currents obtained from altering the external concentration of a transported substrate thereby eliminating other currents without the need for a specific inhibitor. q is determined by the ratio of $\Delta l$ at two different membrane voltages $\left(V_{1}\right.$ and $\left.V_{2}\right)$ where $q=2 R T /\left(F\left(V_{2}-V_{1}\right)\right) \ln \left(\Delta I_{2} / \Delta I_{1}\right)+1$. We tested this $\Delta$ l methodology in HEK-293 cells expressing the elctrogenic SLC4 sodium bicarbonate cotransporters NBCe2-C and NBCe1-A, the results were consistent with those obtained with the $\mathrm{E}_{\mathrm{rev}}$ inhibitor method. Furthermore, using computational simulations, we compared the estimates of $\mathrm{q}$ with the $\Delta \mathrm{E}_{\mathrm{rev}}$ and $\Delta \mathrm{l}$ methods. The results showed that the $\Delta \mathrm{E}_{\mathrm{rev}}$ method introduces significant error when other channels or electrogenic transporters are present on the membrane and that the $\Delta \mathrm{l}$ equation accurately calculates the stoichiometric ratio.
\end{abstract}

Conclusions: We developed a $\Delta \mathrm{l}$ method for estimating transport stoichiometry of electrogenic transporters based on the Heinz model. This model reduces to the conventional reversal potential method when the transporter under study is the only electrogenic transport process in the membrane. When there are other electrogenic transport pathways, $\Delta$ l method eliminates their contribution in estimating q. Computational simulations demonstrated that the $\Delta \mathrm{E}_{\text {rev }}$ method introduces significant error when other channels or electrogenic transporters are present and that the $\Delta$ l equation accurately calculates the stoichiometric ratio. This new $\Delta \mathrm{l}$ method can be readily extended to the analysis of other electrogenic transporters in other tissues.

Keywords: Electrogenic transporter, Stoichiometry, Membrane current-voltage relationship, Reversal potential, HEK-293 cells, Patch clamp, Computational simulation

\section{Background}

Based on their electrical properties, membrane protein transporters are classified as being either electrogenic (transport a net charge) or electroneutral [1-3]. Which of these categories a given transporter belongs to is dependent on its substrate (or ion) coupling ratio; its transport stoichiometry represented by the symbol $\mathrm{q}$.

\footnotetext{
*Correspondence: mshao@ucla.edu

2Department of Neurobiology, David Geffen School of Medicine at UCLA, Los Angeles, CA 90095, USA

Full list of author information is available at the end of the article
}

Electrogenic transporters are sensitive to both the electrical and chemical gradients of the ions that are being transported across a membrane. Unlike electroneutral transporters, electrogenic transporters can utilize the membrane potential of a cell or organelle membrane to drive substrates or ions against their chemical gradients. For a given electrochemical gradient, the transport stoichiometry is therefore an important independent determinant of both the magnitude and direction of substrate or ion flux through a membrane transport protein. The simplest stoichiometry for an electrogenic transporter 
is $1: 1$ as in the case of the sodium-coupled glucose transporter SGLT2 [4]. In many instances more complex stoichiometries have been reported $[4,5]$. Furthermore, certain transporters have variable stoichiometry ratios [6-10].

The most intuitively straightforward approach for measuring the stoichiometry of a transporter is to measure the flux of each transported species either directly [11] or indirectly [12]. In many instances, technical difficulties or sensitivity/specificity considerations preclude interpretable flux measurements from being acquired. Rather than measuring the actual substrate fluxes, a widely used approach is to measure the steady state current-voltage $(\mathrm{I}-\mathrm{V})$ properties of the transporter. In this approach, one determines the reversal potential $\left(\mathrm{E}_{\mathrm{rev}}\right)$, and estimates $\mathrm{q}$ as for example in the case of an electrogenic sodium coupled bicarbonate transporter [1] as follows:

$$
E_{N B C}=\frac{R T}{F(q-1)} \ln \frac{\left[\mathrm{Na}^{+}\right]_{i}\left(\left[\mathrm{HCO}_{3}^{-}\right]_{i}\right)^{q}}{\left[\mathrm{Na}^{+}\right]_{o}\left(\left[\mathrm{HCO}_{3}^{-}\right]_{o}\right)^{q}}
$$

where intracellular concentrations of $\mathrm{Na}^{+}\left(\left[\mathrm{Na}^{+}\right]_{\mathrm{i}}\right)$ and $\mathrm{HCO}_{3}^{-}\left(\left[\mathrm{HCO}_{3}^{-}\right]_{\mathrm{i}}\right)$ as well as extracellular concentrations of $\mathrm{Na}^{+}\left(\left[\mathrm{Na}^{+}\right]_{\mathrm{o}}\right)$ and $\mathrm{HCO}_{3}^{-}\left(\left[\mathrm{HCO}_{3}^{-}\right]_{\mathrm{o}}\right)$ are known and $\mathrm{E}_{\mathrm{NBC}}$ is the reversal potential of the transporter. $\mathrm{F}, \mathrm{R}$ and $\mathrm{T}$ are Faraday's constant, gas constant and absolute temperature respectively. $\mathrm{RT} / \mathrm{F}=25.69$ at $25^{\circ} \mathrm{C}$ [13].

If the electrogenic transporter under consideration is the only transport mechanism in the membrane, q estimated by solving Eq. 1 is accurate. In most cells or expression systems, there are other channels or electrogenic transporters in the membrane, reversal potential method requires the use of a specific inhibitor to differentiate the transport process of interest from other transport pathways. Subtracting the I-V curve in the presence of the inhibitor from the I-V curve without inhibitor, one obtains the $E_{\text {rev }}$ of the transporter-mediated current. Therefore, the relationship of Eq. 1 still holds.

Given that inhibitors are not always as specific as one would prefer, or in circumstances where a specific inhibitor is unavailable, an alternative approach has been to measure the change in zero-current membrane potential $\left(V_{I=0}\right.$, the voltage of the $I-V$ curve measured at $\left.I=0\right)$, by altering the chemical gradient(s) of the transported species [15-16]. Then $\Delta \mathrm{E}_{\mathrm{rev}}$ is

\section{$\Delta E_{\text {rev }}=V_{I=0}$ at a concentration of a substrate - $V_{I=0}$ at another concentration}

There are some variations of the $\Delta \mathrm{E}_{\mathrm{rev}}$ approach such as estimating $\mathrm{q}$ by determining the slope of $\mathrm{V}_{\mathrm{I}=0}$ vs. ion or substrate concentrations [2]. In this report, we show that $\Delta \mathrm{E}_{\mathrm{rev}}$ approach is correct only when the transport current under study is the only current in the membrane or in other words, currents mediated by other channels, electrogenic transporters, and leak current are negligible. When the currents mediated by other channels/transporters are not negligible, the implicit assumption underlying the $\Delta \mathrm{E}_{\mathrm{rev}}$ approach and its variations is that the reversal potentials due to other channels and transporters are additive to the $E_{\text {rev }}$ of the transporter under study, therefore they can be eliminated by subtraction. However, the assumption that $\mathrm{E}_{\mathrm{rev}}$ is additive is not valid since the effect of multiple channels/electrogenic transporters on $\Delta \mathrm{E}_{\mathrm{rev}}$ is a complicated function of the concentrations of ions and substrates involved, as well as the conductance and transport rate of those pathways $[17,18]$.

To address these issues, we have developed a new approach named the "delta current $(\Delta \mathrm{I})$ method". The utility of the $\Delta \mathrm{I}$ approach is demonstrated using the electrogenic sodium bicarbonate cotransporters NBCe2-C and NBCe1A [14,19-21] expressed in HEK-293 cells. In vivo, NBCe2$\mathrm{C}$ is expressed in choroid plexus epithelial cells and other tissues. NBCe1-A is expressed in the mammalian kidney proximal tubule and the eye. This method has several advantages: 1) The equation does not suffer from the aforementioned errors in the $\Delta \mathrm{E}_{\mathrm{rev}}$ method due to other channels and functional electrogenic transporters; 2) Like the $\Delta \mathrm{E}_{\mathrm{rev}}$ method, the measurement protocol does not require a specific inhibitor. In addition, by computational simulations, we show the advantage of the $\Delta \mathrm{I}$ method in calculating the stoichiometry ratio of an electrogenic transporter, and demonstrate that the $\Delta \mathrm{E}_{\mathrm{rev}}$ method can introduce significant errors in estimating $\mathrm{q}$.

\section{Methods}

Expression of NBCe2-C and NBCe1-A in HEK-293 cells

The SLC4 human NBCe2-C and NBCe1-A proteins were expressed in HEK-293 cells as follows. Full-length human cDNA for each transporter was cloned into a pMSCVIRES-EGFP (Clontech, Mountain View, CA) which expresses the transporters under a CMV promoter and also expresses EGFP as a separate protein under an internal ribosome entry site. The cDNA sequence of each of the constructs was verified by DNA sequencing. Use of human material and cell line are approved by UCLA Institutional Biosafety Committee (IBC\#111.13.0-r).

\section{Electrophysiological recordings}

Cells expressing each transporter were cultured in DMEM media with $5 \% \mathrm{FBS} / 5 \% \mathrm{CO}_{2}$ and $37^{\circ} \mathrm{C}$. The cells were transferred to $35 \mathrm{~mm}$ tissue culture (Bioptechs, Butler PA) inserts that were placed on the microscope stage for patch-clamp recording. The cells were continually superfused with bath solution $(\sim 2 \mathrm{ml} /$ min) during the experiments. All experiments were performed in room temperature $\left(22 \pm 1^{\circ} \mathrm{C}\right)$. HEK-293 cells were whole-cell patch-clamped with the aid of 
fluorescent optics (Axioskop2, Carl Zeiss, Göttingen, Germany). Patch pipettes were pulled from thick wall $(0.32 \mathrm{~mm})$ borosilicate glass with tip size 1 - $1.5 \mu \mathrm{m}$ (resistance: 4-6.5 M $\Omega$ ). The patch pipette filling solution and bath solution components are listed in Table 1. All solutions were $\mathrm{pH} 7.4$ that were confirmed with $\mathrm{pH}$ meter measurements in conditions throughout the studies. To ensure stable electrode potentials during whole-cell patch-clamp recordings, a micro-agar salt bridge of $2 \mathrm{M} \mathrm{KCl}$ was built in the electrode holder that formed an electrical connection between the pipette solution and the $\mathrm{Ag} / \mathrm{AgCl}$ wire connected to the headstage of a patch-clamp amplifier [22]. Intracellular signals were amplified and low pass-filtered at $400 \mathrm{~Hz}$ with a patch-clamp amplifier (MultiClamp 700B, Molecular Devices Co., Sunnyvale, CA). Whole cell capacitance and series resistance were determined with the auto whole-cell capacitance and series resistance compensation. The series resistance was usually compensated $80 \%$ (both prediction and correction). Junction potentials generated by different pairs of patch pipette solutions and bath solutions were determined with the junction potential calculator in software Clampex 10 (Molecular Devices Co., Sunnyvale, CA) and reported potential values were corrected for junction potentials. The inhibitor 4,4' -Diisothiocyanatostilbene-

Table 1 Solutions

\begin{tabular}{|c|c|c|c|c|c|c|c|c|c|}
\hline \multirow[t]{2}{*}{ Components } & \multicolumn{4}{|c|}{ Pipette } & \multicolumn{5}{|l|}{ Bath } \\
\hline & $a$ & b & c & $\bar{d}$ & $A$ & B & $C$ & D & $E$ \\
\hline $\mathrm{NaCl}$ & & & & & 110 & 110 & 55 & & 15 \\
\hline $\mathrm{CsCl}$ & & & & & 10 & 10 & 10 & & \\
\hline $\mathrm{CaCl}_{2}$ & 1 & 1 & 1 & 1 & 1.5 & 1.5 & 1.5 & 1.5 & 1.5 \\
\hline $\mathrm{MgCl}_{2}$ & & & & & 1 & 1 & 1 & 1 & 1 \\
\hline TEA-Cl & 10 & 10 & 10 & 10 & & & & & \\
\hline TMA-Cl & & & & & & & 55 & 120 & 105 \\
\hline EGTA & 10 & 10 & 10 & 10 & & & & & \\
\hline HEPES & 10 & 50 & 50 & 50 & 10 & 10 & 10 & 10 & 10 \\
\hline $\mathrm{NaHCO}_{3}$ & & 8 & 25 & 25 & & 25 & 25 & 10 & 10 \\
\hline Cs-Gluconate & 125 & 105 & 105 & 90 & & & & & \\
\hline $\mathrm{Cs}-\mathrm{HCO}_{3}$ & & 17 & & & & & & & \\
\hline $\mathrm{TMA}-\mathrm{HCO}_{3}$ & & & & & & & & 15 & 15 \\
\hline Na-Gluconate & 10 & & & 15 & 25 & & & & \\
\hline ATP-Mg & 1 & 1 & 1 & 1 & & & & & \\
\hline ATP-Na 2 & 1 & 1 & & & & & & & \\
\hline Glucose & & & & & 15 & 15 & 15 & 15 & 15 \\
\hline
\end{tabular}

Bicarbonate-containing solutions were bubbled with $5 \% \mathrm{CO}_{2}$ and $95 \% \mathrm{O}_{2}$. All solutions were $\mathrm{pH}$ 7.4. Glucose was included in the bath solutions to adjust the osmolality to approximately $300 \mathrm{mmol} / \mathrm{Kg}$. The solution osmolality was determined with an osmometer (Model 5520, Vapro ${ }^{\circledR}$ vapor pressure osmometer, Wescor Inc., Logan, UT, USA). 2,2'-disulfonic acid disodium salt (DIDS; SIGMAAldrich Co., St. Louis, MO.) was used to block NBCe2$\mathrm{C}$ and NBCe1-A function.

\section{Data analysis}

Signals from intracellular recordings were digitized at 2 $\mathrm{KHz}$ sampling frequency with the Digidata 1440A and software Clampex 10 (Molecular Devices Co., CA, USA). The signals were saved as data files for further analyses off-line. Data are expressed as mean \pm SE. Paired t-test was used for determining statistical significance. $\mathrm{p} \leq 0.05$ was taken as the criterion for significance.

\section{Results}

Estimation of NBCe2-C transport stoichiometry with the conventional reversal potential method

The light microscopic image of cultured HEK-293 cells and corresponding fluorescent image of the same field is shown in Figure 1a and b respectively. Bright fluorescent cells were EGFP positive and thus were NBCe2-C expressing cells as well. We voltage-clamped EGFP positive cells at a holding voltage $-60 \mathrm{mV}$ and applied a series of $400 \mathrm{~ms}$ pulses from -95 to +45 with increment of 10 $\mathrm{mV}$. The current responses to the series of pulses in pre- $\mathrm{HCO}_{3}{ }^{-}\left(0 \mathrm{HCO}_{3}^{-}\right)$conditions were background current due to endogenous channels in HEK-293 cells (Figure $2 \mathrm{a}$ left panel). We established an I-V curve of steady state current. Figure $2 b$ shows the mean I-V curves from 8 cells. The steady state current at $+45 \mathrm{mV}$ was $51.8 \pm 18.0 \mathrm{pA}($ mean $\pm \mathrm{SE}, \mathrm{n}=8)$. Bath application of a solution containing $25 \mathrm{mM} \mathrm{HCO}_{3}^{-}$(Table 1, bath solution $\mathrm{B}$ ) induced a voltage-dependent current (Figure 2a central panel). The mean I-V curve in the presence of $\mathrm{HCO}_{3}^{-}$is shown in Figure $2 \mathrm{~b}$. The steady state current at voltage $+45 \mathrm{mV}$ was $133.5 \pm 25.5 \mathrm{pA}(\mathrm{p}=0.01$, paired $\mathrm{t}$ test vs pre- $\mathrm{HCO}_{3}^{-}$). The $\mathrm{HCO}_{3}^{-}$-induced current was obtained by subtracting the current traces in the absence of $\mathrm{HCO}_{3}{ }^{-}$from the current traces in its presence. Figure $2 \mathrm{c}$ shows the mean $\mathrm{I}-\mathrm{V}$ curve of $\mathrm{HCO}_{3}^{-}$induced current. The mean $\mathrm{HCO}_{3}{ }^{-}$-induced current at voltage +45 $\mathrm{mV}$ was $81.7 \pm 23.3 \mathrm{pA} \quad(\mathrm{n}=8)$. The current was greatly reduced after washing with the control bath solution (Figure 2a right panel). As a separate control, we tested whether the application of $\mathrm{HCO}_{3}^{-}$containing solution induced any current in EGFP negative cells. As shown in Figure $2 \mathrm{~d}$, there is no significant $\mathrm{HCO}_{3}{ }^{-}$-induced current detected in these cells $(n=4)$. These results indicate that functional $\mathrm{NBCe} 2-\mathrm{C}$ is expressed in EGFP labeled HEK-293 cells and that NBCe2-C transports $\mathrm{HCO}_{3}{ }^{-}$electrogenically.

To estimate the $\mathrm{NBCe} 2-\mathrm{C}_{\mathrm{HCO}_{3}}{ }^{-}$to $\mathrm{Na}^{+}$transport stoichiometry $\mathrm{q}$, the conventional method of measuring the reversal potential with the inhibitor DIDS was used 
b
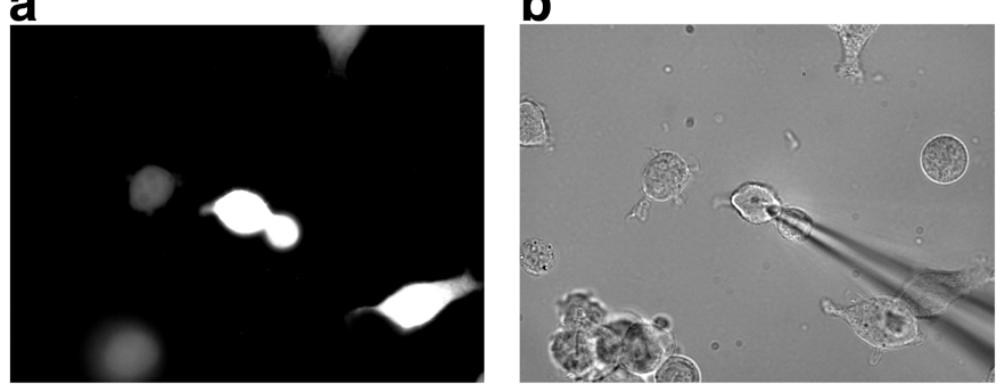

Figure 1 The microscope image of cultured HEK-293 cells and corresponding fluorescent image of the same field. a) Fluorescent microscopic image of HEK-293 cells expressing NBCe2-C and EGFP under separate promoters. b) Light microscope image showing the electrode patched on an EGFP positive cell.

initially. At known intracellular and extracellular concentrations of $\mathrm{Na}^{+}$and $\mathrm{HCO}_{3}{ }^{-}$, q could be estimated with Eq. 1.

In this study, HEK-293 cells expressing NBCe2-C were whole-cell patch-clamped at $-60 \mathrm{mV}$. $\mathrm{V}_{\mathrm{I}=0}$ was measured in two independent experiments where $\left[\mathrm{HCO}_{3}{ }^{-}\right]_{\mathrm{i}}$ and $\left[\mathrm{HCO}_{3}{ }^{-}\right]_{\mathrm{o}}$ were equal $(25 \mathrm{mM})$, therefore $\mathrm{E}_{\mathrm{NBC}}$ depended only on $\left[\mathrm{Na}^{+}\right]_{\mathrm{i}} /\left[\mathrm{Na}^{+}\right]_{\mathrm{o}}$. For every cell recorded, we waited at least $10 \mathrm{~min}$ from establishment of wholecell patch-clamp to ensure that $\left[\mathrm{Na}^{+}\right]_{\mathrm{i}}$ and $\left[\mathrm{HCO}_{3}{ }^{-}\right]_{\mathrm{i}}$ were equal to the concentrations of $\mathrm{Na}^{+}$and $\mathrm{HCO}_{3}{ }^{-}$ respectively in the patch pipette solution by diffusion before beginning I-V measurement. Current responses to a series of voltage pulses were recorded to establish I$\mathrm{V}$ relationship in the absence and presence of DIDS $(0.5$ $\mathrm{mM}$, Figure 3a). In the first experiment, using $\left[\mathrm{Na}^{+}\right]_{\mathrm{i}} /$ $\left[\mathrm{Na}^{+}\right]_{\mathrm{o}}=40 / 80 \mathrm{mM}$ (Patch solution $\mathrm{d} /$ /bath solution $\mathrm{C}$ in Table 1), I-V curve of steady-state NBCe2-C transport current (DIDS sensitive current) was obtained by subtraction of currents in the presence of DIDS from
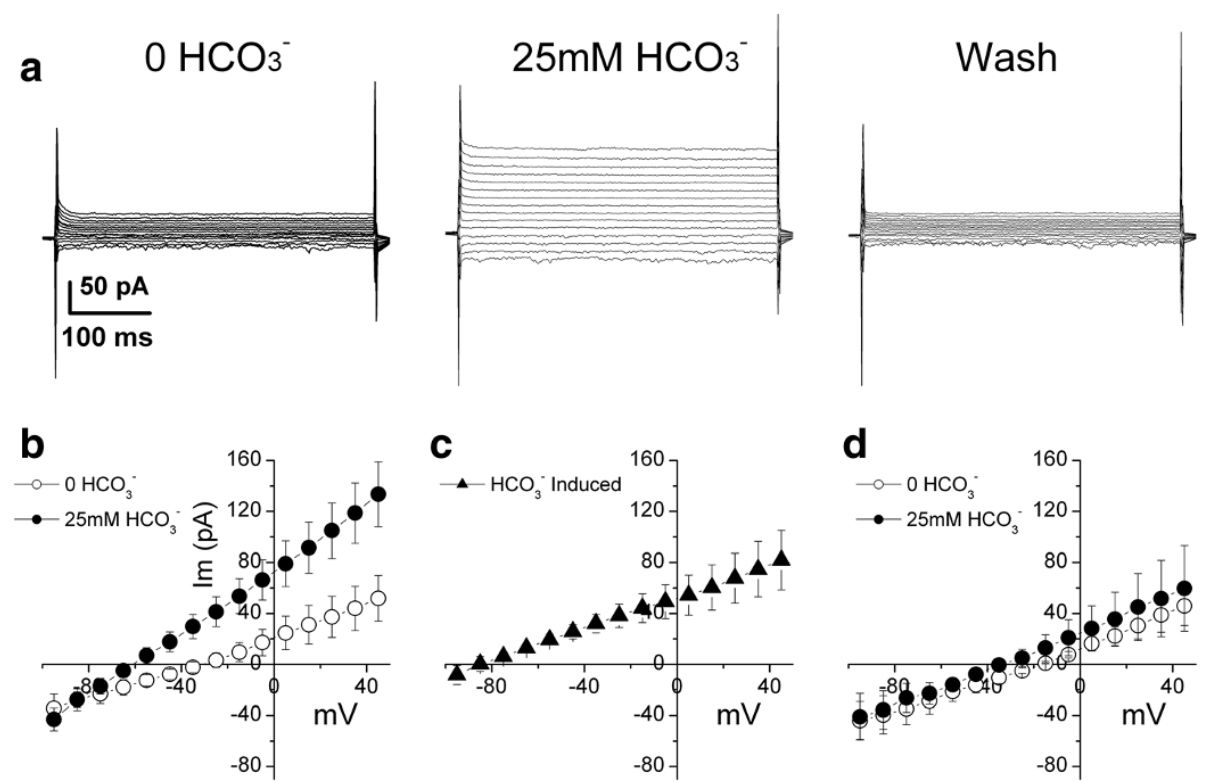

Figure $2 \mathrm{HCO}_{3}^{-}$-induced current in NBCe2-C expressing HEK-293 cells. a) The cell was whole-cell voltage-clamped at -60 mV. A series of 400 ms voltage-clamp pulses range from -95 to $+45 \mathrm{mV}$ with increment of $10 \mathrm{mV}$ were applied and whole-cell current responses were recorded. In the pre- $\mathrm{HCO}_{3}{ }^{-}$conditions, there is no $\mathrm{HCO}_{3}{ }^{-}$in the patch pipette (Table 1, patch solution a) nor in the bath solution (Table 1, Bath solution A). Increasing $\mathrm{HCO}_{3}{ }^{-}$concentration to $25 \mathrm{mM}$ in the bath solution (Bath solution B in Table 1) induced a voltage-dependent current (central panel). The current recovered when the cell was washed with solution containing $\mathrm{O} \mathrm{HCO}_{3}^{-}$(right panel). b) Current-voltage (I-V) relation of steady-state current in the absence and presence of $\mathrm{HCO}_{3}{ }^{-}(\mathrm{n}=8)$. Im $(\mathrm{pA})$ : membrane current in $\mathrm{pA}$. Steady-state current was obtained by averaging $80 \mathrm{~ms}$ of the current trace toward the end of each $400 \mathrm{~ms}$ voltage pulse. c) I-V curve of $\mathrm{HCO}_{3}{ }^{-}$induced current is the difference between the I-V curves in the absence of $\mathrm{HCO}_{3}{ }^{-}$ and in the presence of $\mathrm{HCO}_{3}{ }^{-}$. d) Application of $25 \mathrm{mM} \mathrm{HCO}_{3}^{-}$in the bath did not induce any current in EGFP negative cells $(n=4)$. 
control current (pre-DIDS). $\mathrm{V}_{\mathrm{I}=0}=-22.3 \pm 2.4 \mathrm{mV}(\mathrm{n}=3)$ was obtained (Figure $3 \mathrm{a}, \mathrm{b}$ and $\mathrm{d}$ ). To show the mean and variability among cells, this $\mathrm{V}_{\mathrm{I}=0}$ value was averaged from the $\mathrm{V}_{\mathrm{I}=0}$ of individual sample cells. Note that this mean $V_{I=0}$ value is very close to the $V_{I=0}$ points where the average DIDS-sensitive I-V curve crosses the $\mathrm{x}$-axis in (Figure $3 \mathrm{~b}$ ). In the second experiment using $\left[\mathrm{Na}^{+}\right]_{\mathrm{i}} /$ $\left[\mathrm{Na}^{+}\right]_{\mathrm{o}}=25 / 135 \mathrm{mM}$ (Patch solution $\mathrm{c} /$ bath solution $\mathrm{B}$ in Table 1), we got $V_{I=0}=-43.9 \pm 3.5 \mathrm{mV}(\mathrm{n}=5$, Figure 3c and $d$ ). The two $V_{I=0}$ values are close to the calculated $\mathrm{E}_{\mathrm{NBC}}$ values of -17.8 and $-43.3 \mathrm{mV}$ (Eq. 1), respectively, assuming $\mathrm{q}=2$ (dash lines) while significantly distinct from the calculated values assuming $\mathrm{q}=3$ (dash lines, Figure 3d). The results indicate that the transport stoichiometry ratio of NBCe2-C is $2 \mathrm{HCO}_{3}{ }^{-}: 1 \mathrm{Na}^{+}$or $\left(1 \mathrm{CO}_{3}{ }^{2-}: 1 \mathrm{Na}^{+}\right)$in HEK-293 cells.

\section{A novel delta current method for estimation of transport stoichiometry}

Based on a simplified model for electrogenic secondary active transport [23] (as originally applied to the $\mathrm{Na}^{+} / \mathrm{Ca}^{2+}$ transporter), in the case of an electrogenic NBC transporter, the $\mathrm{Na}^{+}-\mathrm{HCO}_{3}{ }^{-}$flux $\left(\mathrm{J}_{\mathrm{c}}\right)$ is shown in Eq. 2. Although we limit our evidence for the validity of our method to electrogenic NBC transporters, the approach is applicable to other electrogenic transporters.

$$
\begin{aligned}
J_{c}= & K_{c}\left\{\left(\left[N a^{+}\right]_{o} \exp \left(-\frac{F V}{R T} \frac{z_{N a}}{2}\right)\right)^{v_{N a}}\right. \\
& \times\left(\left[\mathrm{HCO}_{3}{ }^{-}\right]_{o} \exp \left(-\frac{F V}{R T} \frac{z_{\mathrm{HCO}_{3}}}{2}\right)\right)^{v_{\mathrm{HCO}_{3}}} \\
& -\left(\left[\mathrm{Na}^{+}\right]_{i} \exp \left(-\frac{F V}{R T} \frac{-z_{N a}}{2}\right)\right)^{v_{N a}} \\
& \left.\times\left(\left[\mathrm{HCO}_{3}{ }^{-}\right]_{i} \exp \left(-\frac{F V}{R T} \frac{-z_{\mathrm{HCO}_{3}}}{2}\right)\right)^{v_{\mathrm{HCO}_{3}}}\right\}
\end{aligned}
$$

where $K_{c}$ is an involved function of mobility and concentrations of free and loaded carrier [23] (also refer to $[24]) . \mathrm{z}_{\mathrm{Na}}$ is the valence of $\mathrm{Na}^{+}$and $v_{\mathrm{Na}}$ is the stoichiometry of $\mathrm{Na}^{+} \cdot v_{\mathrm{HCO} 3}$ is the stoichiometry of $\mathrm{HCO}_{3}^{-} \cdot \mathrm{V}$ is the membrane potential. The total membrane current is:

$$
\begin{aligned}
I_{M}=F K_{c}\{ & \left(\left[\mathrm{Na}^{+}\right]_{o} \exp \left(-\frac{F V}{2 R T}\right)\right)^{v_{N a}} \\
& \times\left(\left[\mathrm{HCO}_{3}{ }^{-}\right]_{o} \exp \left(\frac{F V}{2 R T}\right)\right)^{v_{H C O}} \\
& -\left(\left[\mathrm{Na}^{+}\right]_{i} \exp \left(\frac{F V}{2 R T}\right)\right)^{v_{N a}} \\
& \left.\times\left(\left[\mathrm{HCO}_{3}{ }^{-}\right]_{i} \exp \left(-\frac{F V}{2 R T}\right)\right)^{v_{\mathrm{HCO}_{3}}}\right\}+\sum_{j} I_{j}
\end{aligned}
$$
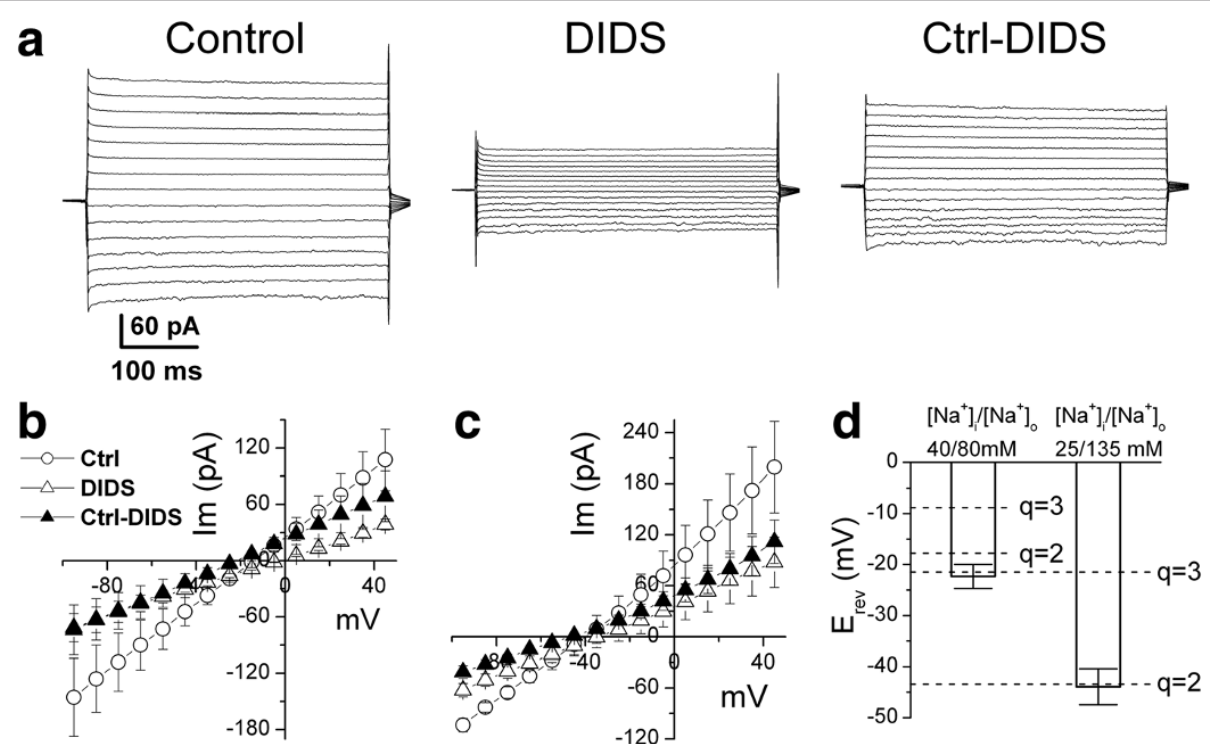

Figure 3 Estimation of transport stoichiometry for NBCe2-C using conventional reversal potential method. a) In the conditions of equal concentrations $(25 \mathrm{mM})$ of $\mathrm{HCO}_{3}^{-}$intra- and extracellularly, the ratio of intracellular concentration of $\mathrm{Na}^{+}\left(\left[\mathrm{Na}^{+}\right]_{i}\right)$ and extracellular concentration of $\mathrm{Na}^{+}\left(\left[\mathrm{Na}^{+}\right]_{0}\right)=40 / 80 \mathrm{mM}$ (Patch solution d/bath solution C in Table 1), cells were voltage-clamped at $-60 \mathrm{mV}$. Current responses to a series of 400 $\mathrm{mV}$ voltage pulses from -95 to $+45 \mathrm{mV}$ with increment of $10 \mathrm{mV}$ were recorded in the absence (pre-DIDS Control, Ctrl) and presence of DIDS (0.5 mM). DIDS sensitive current (right panel, Ctrl-DIDS) was obtained by digital subtraction of currents in the presence of DIDS (center panel) from control current $(n=3)$. B) I-V relations of steady-state current in Ctrl, DIDS and Ctrl-DIDS conditions. c) I-V curves obtained with the same protocol as (b) except $\left[\mathrm{Na}^{+}\right]_{i} /\left[\mathrm{Na}^{+}\right]_{0}=25 / 135 \mathrm{mM}$ (Patch solution $\mathrm{c} /$ bath solution $B$ in Table 1) $(n=5)$. d) The two $V_{l=0}$ values are close to the calculated values assuming $q=2$ (dash lines) while significantly distinct from the calculated values assuming $q=3$ (dash lines). 
Where $\sum_{j} I_{j}$ is the sum of all other currents mediated by various channels and electrogenic transporters including leak current on the membrane. $\sum_{j} I_{j}$ can be a non-linear function of $\mathrm{V}$ while a general assumption is that it is independent of NBC transport current.

If we change the $\mathrm{Na}^{+}$concentration outside the cell from $\left[\mathrm{Na}^{+}\right]_{\mathrm{o} 1}$ to $\left[\mathrm{Na}^{+}\right]_{\mathrm{o} 2}$, the whole cell current would change from $I_{M 1}$ to $I_{M 2}$. We assume that $K_{c}$ does not vary with $\left[\mathrm{Na}^{+}\right]_{0}$ within a range far from saturation. We also assume that the sum of other currents $\sum j I_{j}$ is a function of $\mathrm{V}$ while the function is unchanged when $\left[\mathrm{Na}^{+}\right]_{\text {o }}$ changes (see Discussion). Therefore the delta current is

$$
\begin{aligned}
\Delta I_{M}=I_{M 2}-I_{M 1}=F K_{c}\{ & \left(\left[N a^{+}\right]_{o 2} \exp \left(-\frac{F V}{2 R T}\right)\right)^{v_{N a}} \\
& \times\left(\left[\mathrm{HCO}_{3}{ }^{-}\right]_{o} \exp \left(\frac{F V}{2 R T}\right)\right)^{v_{H C O_{3}}} \\
& -\left(\left[\mathrm{Na}^{+}\right]_{o 1} \exp \left(-\frac{F V}{2 R T}\right)\right)^{v_{N a}} \\
& \left.\times\left(\left[\mathrm{HCO}_{3}{ }^{-}\right]_{o} \exp \left(\frac{F V}{2 R T}\right)\right)^{v_{H C O_{3}}}\right\}
\end{aligned}
$$

$\sum_{j} I_{j}$ is completely eliminated. For simplicity, we take $v_{\mathrm{Na}}=1$ and $\mathrm{q}=v_{\mathrm{HCO} 3} / v_{\mathrm{Na}}$.

Now we consider at two different voltage points $V_{1}$ and $\mathrm{V}_{2}$, we have two $\Delta \mathrm{I}_{\mathrm{M}}$ values, $\Delta \mathrm{I}_{\mathrm{V} 1}$ and $\Delta \mathrm{I}_{\mathrm{V} 2}$. We take the ratio of them,

$$
\frac{\Delta I_{V 2}}{\Delta I_{V 1}}=\frac{F K_{c}\left\{\left(\left[\mathrm{Na}^{+}\right]_{o 2}-\left[N a^{+}\right]_{o 1}\right) \exp \left(-\frac{F V_{2}}{2 R T}\right) \cdot\left(\left[\mathrm{HCO}_{3}{ }^{-}\right]_{o} \exp \left(\frac{F V_{2}}{2 R T}\right)\right)^{q}\right\}}{F K_{c}\left\{\left(\left[\mathrm{Na}^{+}\right]_{o 2^{-}}\left[\mathrm{Na}^{+}\right]_{o 1}\right) \exp \left(-\frac{F V_{1}}{2 R T}\right) \cdot\left(\left[\mathrm{HCO}_{3}\right]_{o} \exp \left(\frac{F V_{1}}{2 R T}\right)\right)^{q}\right\}}
$$

$\Delta \mathrm{I}_{\mathrm{V} 1}$ and $\Delta \mathrm{I}_{\mathrm{V} 2}$ can be measured in electrophysiological experiments, therefore, there is only one unknown q. q can be expressed as

$$
q=\frac{2 R T}{F\left(V_{2}-V_{1}\right)} \ln \frac{\Delta I_{V 2}}{\Delta I_{V 1}}+1
$$

In practical situations, to minimize the effect of the possible voltage dependence of $\mathrm{K}_{\mathrm{c}}$ on the measurement of $\Delta \mathrm{I}_{\mathrm{M}}$ and estimation of $\mathrm{q}$, we take $\left[\mathrm{Na}^{+}\right]_{\mathrm{o} 1}=\left[\mathrm{Na}^{+}\right]_{\mathrm{i}}$ and $\left[\mathrm{HCO}_{3}^{-}\right]_{\mathrm{o}}=\left[\mathrm{HCO}_{3}^{-}\right]_{\mathrm{i}}$, where

$$
I_{M}=\sum_{j} I_{j} \text { at } V=0 .
$$

Therefore, at $\mathrm{V}=0$, the delta current $\Delta \mathrm{I}_{\mathrm{V} 1=0}$ is the pure $\mathrm{NBC}$ transport current at $\left[\mathrm{Na}^{+}\right]_{\mathrm{o} 2}$. $\mathrm{q}$ is as simple as

$$
q=\frac{2 R T}{F V_{2}} \ln \frac{\Delta I_{V 2}}{\Delta I_{V 1=0}}+1
$$

In the following applications, to minimize the effects of possible $K_{c}$ voltage dependence, we also take a $V_{2}$ value close to 0 (e.g. \pm 10 to $15 \mathrm{mV}$ ). Therefore the calculation involves only experimental measurements of currents close to equilibrium conditions.

\section{Transport stoichiometry of NBCe2-C estimated with the delta current method}

Under the conditions that $\left[\mathrm{Na}^{+}\right]_{\mathrm{i}}=\left[\mathrm{Na}^{+}\right]_{\mathrm{o}}=10 \mathrm{mM}$ and $\left[\mathrm{HCO}_{3}{ }^{-}\right]_{\mathrm{i}}=\left[\mathrm{HCO}_{3}{ }^{-}\right]_{\mathrm{o}}=25 \mathrm{mM}$ (patch solution $\mathrm{b}$ and bath solution D in Table 1), NBCe2-C expressing HEK293 cells were voltage-clamped at $-50 \mathrm{mV}$ and a series of voltage (including a pulse to $0 \mathrm{mV}$ ) was applied (Figure 4a, left panel). Increasing the $\mathrm{Na}^{+}$concentration from 10 to $25 \mathrm{mM}$ in the bath solution (bath solution $\mathrm{E}$ in Table 1) increased the voltage-dependent current (Figure 4a, central panel). Net current $(\Delta \mathrm{I})$ through $\mathrm{NBCe} 2-\mathrm{C}$ induced by changing $\left[\mathrm{Na}^{+}\right]_{\mathrm{o}}$ was obtained by subtracting the currents in bath solution containing $10 \mathrm{mM} \mathrm{Na}{ }^{+}$from currents in $25 \mathrm{mM}\left[\mathrm{Na}^{+}\right]_{\mathrm{o}}$ (Figure 4a, right panel). With this operation, according to Eq. 4, currents mediated by other channels and electrogenic transporters were eliminated if the two assumptions associated with Eq. 4 were satisfied. Figure $4 \mathrm{~b}$ shows current-voltage (I-V) relation of steadystate current in bath solution containing $10 \mathrm{mM}$ or 25 $\mathrm{mM}\left[\mathrm{Na}^{+}\right]_{\mathrm{o}}$ and Figure $4 \mathrm{c}$ shows $\Delta \mathrm{I}$ of NBCe2-C vs. voltages. Taking $\Delta \mathrm{I}_{\mathrm{v} 1}$ at $\mathrm{V}=0$ and $\Delta \mathrm{I}_{\mathrm{v} 2}$ at $\mathrm{V}=12 \mathrm{mV}$, q is calculated using Eq. 7. We obtained $q=2.0 \pm 0.14(n=5$, Figure $4 \mathrm{~d}$ ). The results suggest that the transport stoichiometry ratio of $\mathrm{NBCe} 2-\mathrm{C}$ is $2 \mathrm{HCO}_{3}^{-}: 1 \mathrm{Na}^{+}$(or $1 \mathrm{CO}_{3}{ }^{2-}: 1$ $\mathrm{Na}^{+}$) in HEK-293 cells. This result is consistent with the $\mathrm{q}$ value obtained with the conventional reversal potential method using the inhibitor DIDS (Figure 3).

\section{Transport stoichiometry of NBCe1-A estimated with the delta current method}

Cells expressing NBCe1-A were voltage-clamped at -50 $\mathrm{mV}$, and whole-cell currents were recorded when a series of voltage pulses was applied (Figure 5a). Using the same conditions as above that $\left[\mathrm{Na}^{+}\right]_{\mathrm{i}}=\left[\mathrm{Na}^{+}\right]_{\mathrm{o}}=10 \mathrm{mM}$ and $\left[\mathrm{HCO}_{3}{ }^{-}\right]_{\mathrm{i}}=\left[\mathrm{HCO}_{3}{ }^{-}\right]_{\mathrm{o}}=25 \mathrm{mM}$ (patch solution $\mathrm{b}$ and bath solution D in Table 1), increasing the $\mathrm{Na}^{+}$concentration from 10 to $25 \mathrm{mM}$ in the bath solution (bath solution was switched from solution $\mathrm{D}$ to solution $\mathrm{E}$ of Table 1) increased voltage-dependent current (Figure 5a middle panel). The net current $(\Delta \mathrm{I})$ through NBCe1-A induced by changing $\left[\mathrm{Na}^{+}\right]_{\mathrm{o}}$ (right panel of Figure $5 \mathrm{a}$ ) was obtained by subtracting the current traces in the solution containing 10 $\mathrm{mM}\left[\mathrm{Na}^{+}\right]_{\mathrm{o}}$ from those in $25 \mathrm{mM}\left[\mathrm{Na}^{+}\right]_{\mathrm{o}}$. The current- 

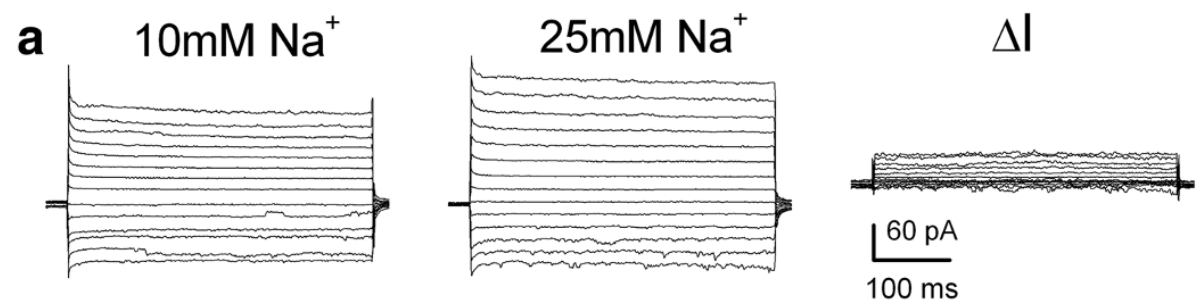

b

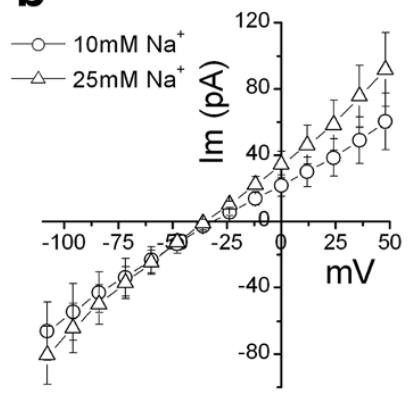

C

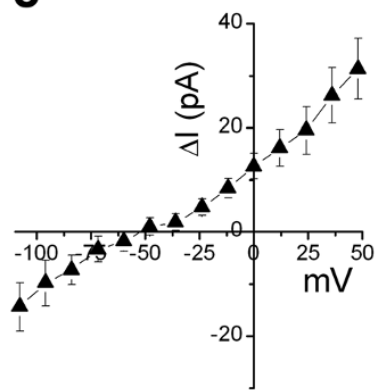

d

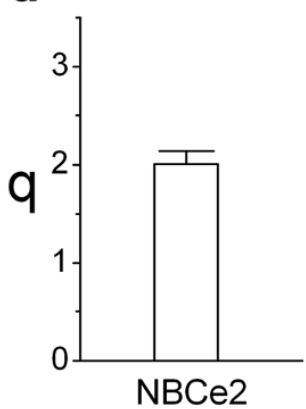

Figure 4 Estimation of transport stoichiometry for NBCe2-C using the delta current method. a) NBCe2-C expressing cells were voltage clamped at $-50 \mathrm{mV}$. A series of $400 \mathrm{~ms}$ voltage-clamp pulses range from -108 to $+48 \mathrm{mV}$ with increment of $12 \mathrm{mV}$ (containing a pulse to $0 \mathrm{mV}$ during this protocol) was applied and whole-cell current responses were recorded. Patch pipette solution contained $10 \mathrm{mM} \mathrm{Na}^{+}$and $25 \mathrm{mM}$ $\mathrm{HCO}_{3}{ }^{-}$(Solution b in Table 1). Bath solution also contained $10 \mathrm{mM} \mathrm{Na}^{+}$and $25 \mathrm{mM} \mathrm{HCO}_{3}{ }^{-}$(Bath solution $\mathrm{D}$ in Table 1) (left panel). Enhancing Na concentration from 10 to $25 \mathrm{mM}$ in the bath solution (Bath solution E in Table 1) increased voltage-dependent current (central panel). Net current ( $\Delta \mathrm{l}$ ) through NBCe2-C induced by changing $\left[\mathrm{Na}^{+}\right]_{\circ}$ is obtained by subtracting the current traces at $\left[\mathrm{Na}^{+}\right]_{\circ}=10 \mathrm{mM}$ from the current traces at $\left[\mathrm{Na}^{+}\right]_{\circ}=25$ $\mathrm{mM}$ (right panel). b) Current-voltage (I-V) relations of steady-state current (mean of $80 \mathrm{~ms}$ current trace toward the end of each voltage pulse) in bath solutions containing $10 \mathrm{mM}$ and $25 \mathrm{mM} \mathrm{Na}^{+}$. c) I-V relation of $\Delta$. d) Estimation of transport stoichiometry ratio q with Eq. $7(\mathrm{n}=5)$.

voltage (I-V) relation of steady-state currents in bath solution containing $10 \mathrm{mM}$ or $25 \mathrm{mM} \mathrm{Na}^{+}$is shown in Figure $5 \mathrm{~b})$. Figure $5 \mathrm{c}$ shows $\Delta \mathrm{I}$ of NBCe1-A vs. membrane voltages. This was the result of operation of Eq. 4 and the currents mediated by other channels and electrogenic transporters were eliminated. Taking $\Delta \mathrm{I}_{\mathrm{V} 1}$ at $\mathrm{V}=0$ and $\Delta \mathrm{I}_{\mathrm{V} 2}$ at $\mathrm{V}=12 \mathrm{mV}$, we calculated $\mathrm{q}$ using Eq. 7 for every cell. We determined $q=1.87 \pm 0.062(n=6$, Figure $5 d)$. The results indicate that the transport stoichiometry ratio of NBCe1-A is $2 \mathrm{HCO}_{3}{ }^{-}: 1 \mathrm{Na}^{+}$or $1 \mathrm{CO}_{3}{ }^{2-}: 1 \mathrm{Na}^{+}$in HEK-293 cells. This estimate is consistent with our previous results using the conventional reversal potential method with DIDS [25].

\section{Computational simulation: $\Delta \mathrm{l}$ method estimates $\mathrm{q}$ accurately when there are additional conductances other than electrogenic NBC transport}

In native tissue or expression systems such as oocytes or HEK-293 cells, there are endogenous channels and electrogenic transporters other than the one under study. In these cases, the $\Delta$ current method is based on the assumption of additivity of membrane currents while the $\Delta \mathrm{E}_{\mathrm{rev}}$ method and its variations based on the assumption of additivity of reversal potentials $[2,15,16]$. Were the latter true, by altering the concentrations of the transported species, the contribution of other channels and electrogenic transporters could be subtracted and the relationship between delta $\mathrm{E}_{\mathrm{rev}}$ and transported species concentrations and the transport stoichiometry easily obtained based on Eq. 1. This method, although widely used, is not consistent with Goldman-Hodgkin-Katz (GHK) theory $[17,18]$ where $\mathrm{E}_{\mathrm{rev}}$ is a logarithmic function of sum of concentrations of ions inside and outside of the membrane; i.e. not additive.

Now, suppose there is one kind of channel that is permeable to a univalent ion with valence $\mathrm{z}_{\mathrm{s}}$ and permeability of $\mathrm{P}_{\mathrm{s}}$ on the cell membrane, in addition to an electrogenic NBC transporter. Based on Eq. 2 and the GHK current equation (with all original GHK assumptions applied [18]), the current would be

$$
\begin{aligned}
I=F K_{C} & \left\{\left(\left[N a^{+}\right]_{0} \exp \left(-\frac{F V}{2 R T}\right)\right)^{V_{N a}} \cdot\left(\left[\mathrm{HCO}_{3}{ }^{-}\right]_{0} \exp \left(\frac{F V}{2 R T}\right)\right)^{V_{H C O_{3}}}\right. \\
& \left.-\left(\left[N a^{+}\right]_{i} \exp \left(\frac{F V}{2 R T}\right)\right)^{V_{N a}} \cdot\left(\left[\mathrm{HCO}_{3}{ }^{-}\right]_{i} \exp \left(-\frac{F V}{2 R T}\right)\right)^{V_{H C O_{3}}}\right\} \\
& +P_{s} Z_{s}^{2} \frac{F V}{R T} \frac{[S] i-[S]_{0} \exp \left(-Z_{s} \frac{F V}{R T}\right)}{1-\exp \left(-Z_{s} \frac{F V}{R T}\right)}
\end{aligned}
$$

At $\mathrm{V}_{\mathrm{I}=0}$ of the electrogenic NBC transporter plus one channel system 

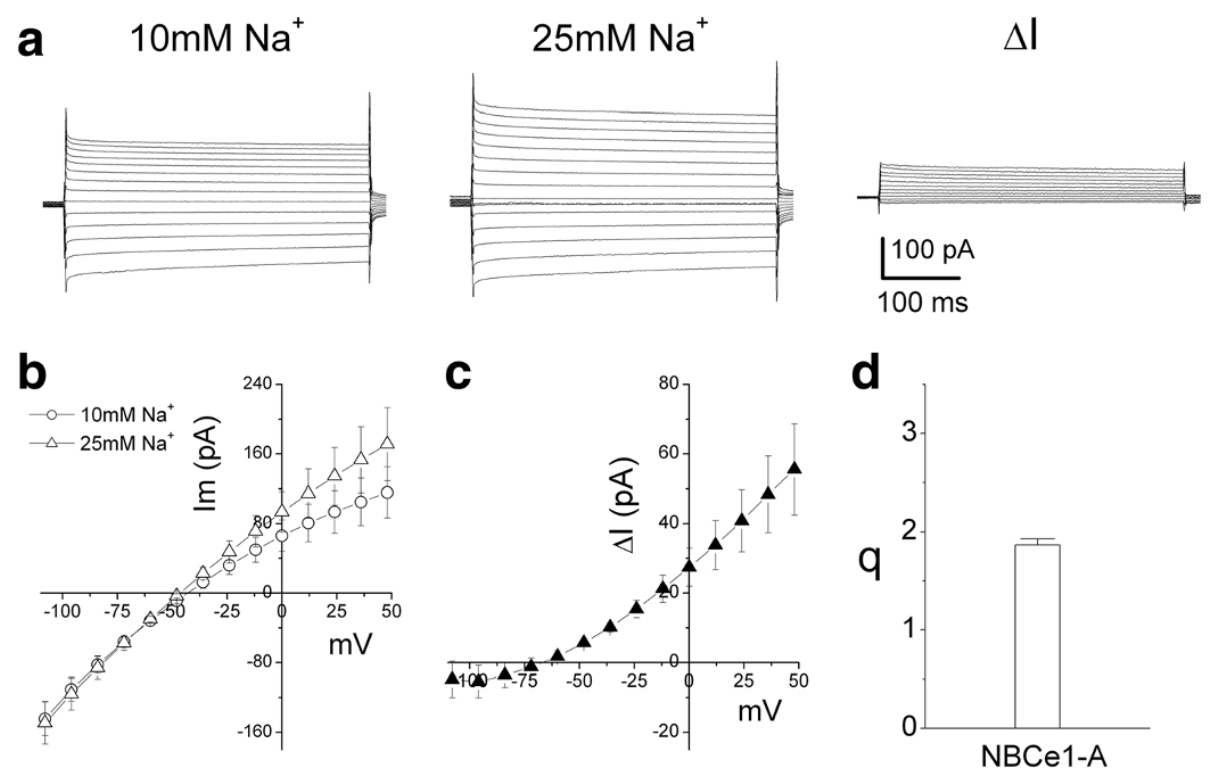

Figure 5 Estimation of transport stoichiometry for NBCe1-A using the delta current method. a) NBCe1-A expressing cells were voltage clamped at $-50 \mathrm{mV}$. A series of $400 \mathrm{~ms}$ voltage-clamp pulses range from -108 to $+48 \mathrm{mV}$ with increment of $12 \mathrm{mV}$ (containing a pulse to $0 \mathrm{mV}$ during this protocol) was applied and whole-cell current responses were recorded. Patch pipette solution contained $10 \mathrm{mM} \mathrm{Na}^{+}$and $25 \mathrm{mM}$ $\mathrm{HCO}_{3}^{-}$(Solution b in Table 1). Bath solution also contained $10 \mathrm{mM} \mathrm{Na}{ }^{+}$and $25 \mathrm{mM} \mathrm{HCO}-$ (Bath solution D in Table 1) (left panel). Enhancing $\mathrm{Na}^{+}$concentration from 10 to $25 \mathrm{mM}$ in the bath solution (Bath solution $\mathrm{E}$ in Table 1). increased voltage-dependent current (central panel). Net current $(\Delta \mathrm{l})$ through NBCe1-A induced by changing $\left[\mathrm{Na}^{+}\right]_{0}$ was obtained by subtracting the current traces at $\left[\mathrm{Na}^{+}\right]_{0}=10 \mathrm{mM}$ from the current traces at $\left[\mathrm{Na}^{+}\right]_{\circ}=25 \mathrm{mM}$ (right panel). b) Current-voltage (I-V) relations of steady-state current (mean of $80 \mathrm{~ms}$ current trace toward the end of each voltage pulse) in bath solutions containing $10 \mathrm{mM}$ and $25 \mathrm{mM} \mathrm{Na}^{+}$. c) I-V relation of $\Delta \mathrm{l}$. d) Estimation of transport stoichiometry ratio q with Eq. $7(n=6)$.

$$
\begin{aligned}
F K_{c} & \left\{\left(\left[N a^{+}\right]_{o} \exp \left(-\frac{F V_{I=0}}{2 R T}\right)\right)^{v_{N a}} \cdot\left(\left[H C O_{3}{ }^{-}\right]_{o} \exp \left(\frac{F V_{I=0}}{2 R T}\right)\right)^{v_{H C O_{3}}}\right. \\
& -\left(\left[N a^{+}\right]_{i} \exp \left(\frac{F V_{I=0}}{2 R T}\right)\right)^{v_{N a}} \\
& \left.\times\left(\left[H C O_{3}^{-}\right]_{i} \exp \left(-\frac{F V_{I=0}}{2 R T}\right)\right)^{v_{H C O_{3}}}\right\} \\
& +P_{S} \exp \left(\frac{F^{2} V_{I=0}}{R T}\right) \frac{\left[s^{+}\right]_{i}-\left[s^{+}\right]_{o} \exp \left(-z_{S} \frac{F V_{I=0}}{R T}\right)}{1-\exp \left(-z_{S} \frac{F V_{I=0}}{R T}\right)}=0
\end{aligned}
$$

We can see that even with one additional channel, this equation contains more than one unknown such as $\mathrm{K}_{\mathrm{c}}, \mathrm{P}_{\mathrm{s}}$ and $v_{\mathrm{HCO} 3}$. What we measure in the electrophysiological experiments is $\mathrm{V}_{\mathrm{I}=0} . \mathrm{V}_{\mathrm{I}=0}$ is a complicated non-additive function of $E_{N B C}$. A simple expression for the relationship between stoichiometry and reversal potential is not obtained. We will see a similar situation when there is one additional electrogenic cotransporter transporting ions s1 and s2 with involved function $K_{a}$, valence $Z_{s 1}$ and $Z_{s 2}$, stoichiometry $v_{\mathrm{s} 1}$ and $v_{\mathrm{s} 2}$ respectively:

$$
\begin{aligned}
I_{M}=F K_{c}\{ & \left(\left[N a^{+}\right]_{o} \exp \left(-\frac{F V}{2 R T}\right)\right)^{v_{N a}} \cdot\left(\left[H C O_{3}{ }^{-}\right]_{o} \exp \left(\frac{F V}{2 R T}\right)\right)^{v_{H C O_{3}}} \\
& \left.-\left(\left[N a^{+}\right]_{i} \exp \left(\frac{F V}{2 R T}\right)\right)^{v_{N a}} \cdot\left(\left[H C O_{3}{ }^{-}\right]_{i} \exp \left(-\frac{F V}{2 R T}\right)\right)^{v_{H C O_{3}}}\right\} \\
& +F K_{a}\left\{\left([s 1]_{o} \exp \left(-\frac{F V z_{s 1}}{2 R T}\right)\right)^{v_{s 1}} \cdot\left([s 2]_{o} \exp \left(-\frac{F V z_{s 2}}{2 R T}\right)\right)^{v_{s 2}}\right. \\
& \left.-\left([s 1]_{i} \exp \left(\frac{F V z_{s 1}}{2 R T}\right)\right)^{v_{s 1}} \cdot\left([s 2]_{i} \exp \left(\frac{F V z_{s 2}}{2 R T}\right)\right)^{v_{s 2}}\right\}
\end{aligned}
$$

Again, a simple expression for the relationship between stoichiometry and reversal potential is not obtained.

We performed a computational simulation of membrane currents and reversal potentials to show how a conductance in addition to electrogenic NBC transport affects the measurement of $\mathrm{V}_{\mathrm{I}=0}$ and thus the estimate of $\mathrm{q}$ for this electrogenic NBC. Based on Eq. 2, currents were calculated with the same conditions as our whole-cell patch-clamp experiments for estimating q (delta current method above) of NBCe2-C: $\left[\mathrm{HCO}_{3}^{-}\right]_{\mathrm{i}}=\left[\mathrm{HCO}_{3}{ }^{-}\right]_{\mathrm{o}}=25$, $\left[\mathrm{Na}^{+}\right]_{\mathrm{i}}=10 \mathrm{mM}$. Assuming $\mathrm{q}=2$, Figure $6 \mathrm{a}$ shows $\mathrm{I}-\mathrm{V}$ curves and $\mathrm{V}_{\mathrm{I}=0} \mathrm{~S}$ when the bath solution switched from $\left[\mathrm{Na}^{+}\right]_{\mathrm{o}}=10 \mathrm{mM}$ to $25 \mathrm{mM}$ and the delta current $(\Delta \mathrm{I})$. The stoichiometry ratios estimated either with the $\Delta \mathrm{E}_{\text {rev }}$ or $\Delta \mathrm{I}$ methods are equivalent when there was no conductance other than the electrogenic NBC transporter 


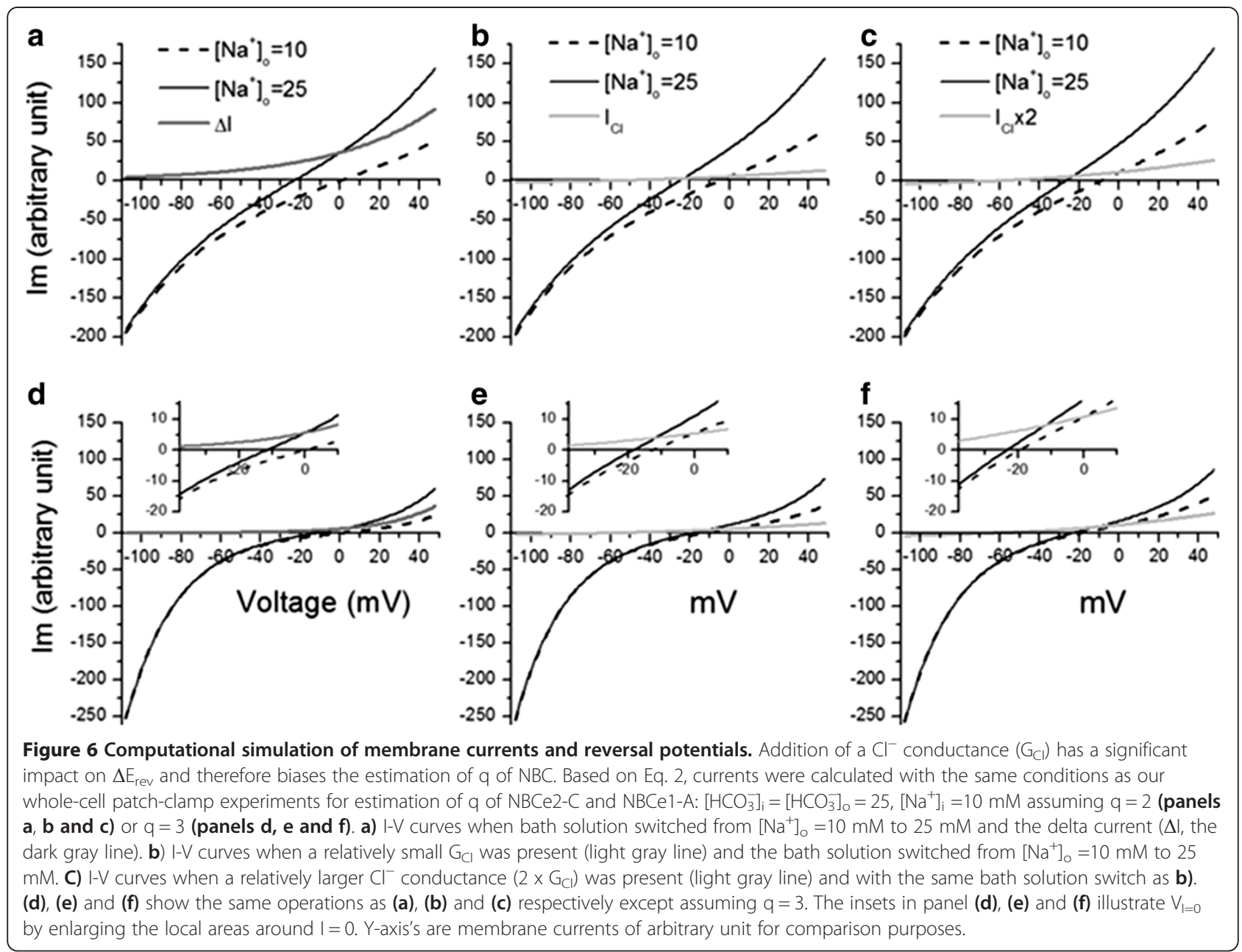

(Table 2). However, if a small $\mathrm{Cl}^{-}$conductance (compared to the conductance of the NBC-mediated current) was present, simulation with Eq. 8 showed that both $\mathrm{V}_{\mathrm{I}=0}$ values at $\left[\mathrm{Na}^{+}\right]_{\mathrm{o}}=10 \mathrm{mM}$ and $\left[\mathrm{Na}^{+}\right]_{\mathrm{o}}=25$ $\mathrm{mM}$ shifted toward more negative value, but the shifts for the two conditions were different (Figure 6b). Therefore $\Delta \mathrm{E}_{\text {rev }}$ differed from that obtained without the $\mathrm{Cl}^{-}$conductance and leads to a different estimate of $\mathrm{q}=$ 2.17. When the $\mathrm{Cl}^{-}$conductance was doubled, the estimate of $q$ became 2.33 (Figure 6c). When we input $q=3$ in the simulation, the estimate was 3 in the absence of any other conductance. After introducing either a small $\mathrm{Cl}^{-}$ conductance $\mathrm{G}_{\mathrm{Cl}}$ or $2 \times \mathrm{G}_{\mathrm{Cl}}$ (same as above), the estimate of $\mathrm{q}$ became 4.96 and 7.2 respectively with the $\Delta \mathrm{E}_{\mathrm{rev}}$ method (Figure 6d,e and f; note the insets; Table 2). However as shown in Table 2, the value of q determined using the $\Delta \mathrm{I}$ method was unaffected by addition of a $\mathrm{G}_{\mathrm{Cl}}$ on the membrane. Specifically, the $\Delta \mathrm{I}-\mathrm{V}$ curves in the absence, presence of small or large $\mathrm{G}_{\mathrm{Cl}}$ were identical. Therefore, the currents mediated by other channels had been eliminated in the procedure and had no effect on the estimation of q.
We then simulated NBCe1-A transport in conditions similar to the proximal tubule cells in the rat kidney where the ionic concentrations (in $\mathrm{mM}$ ) were $\left[\mathrm{HCO}_{3}{ }^{-}\right]_{\mathrm{o}}=$ 24, $\left[\mathrm{HCO}_{3}^{-}\right]_{\mathrm{i}}=13.4,\left[\mathrm{Na}^{+}\right]_{\mathrm{o}}=150$ and $\left[\mathrm{Na}^{+}\right]_{\mathrm{i}}=17 \mathrm{mM}[26]$. In addition to NBCe1-A, the $\mathrm{Na}^{+} / \mathrm{D}$-glucose cotransporter SGLT2 was modeled in the simulation. SGLT2 is expressed in the apical membrane of proximal tubule cells and exhibits a transport stoichiometry of $1 \mathrm{Na}^{+}: 1$ glucose [27]. One positive charge moves across the membrane per transport cycle. An extracellular glucose concentration $[G]_{0}=5$ $\mathrm{mM}$ and intracellular $[G]_{\mathrm{i}}=1 \mathrm{mM}$ were substituted into Eq. 10 assuming $q=2$ or 3 for NBCe1-A. Table 3 shows the $\mathrm{V}_{\mathrm{I}=0}$ values when $\left[\mathrm{Na}^{+}\right]_{\mathrm{o}}=150$ and when $\left[\mathrm{Na}^{+}\right]_{\mathrm{o}}$ was switched to 100 in the absence and presence of SGLT2. The simulation also provided estimated $\mathrm{q}$ values by $\Delta \mathrm{E}_{\mathrm{rev}}$ and $\Delta \mathrm{I}$ methods. The stoichiometry ratios estimated either with the $\Delta \mathrm{E}_{\mathrm{rev}}$ or $\Delta \mathrm{I}$ methods were equivalent when SGLT2 was absent. However, when SGLT2 was present, q was 2.55 estimated with the $\Delta \mathrm{E}_{\text {rev }}$ method when the actual value in the simulation was 3 (Table 3). The presence of SGLT2 prevents any definitive determination as to whether the stoichiometry of NBCe1-A is $q=2$ or $q=3$. 
Table 2 Computational simulation of $\Delta \mathrm{I}$ and $\Delta \mathrm{E}_{\mathrm{rev}}$ methods to estimate $\mathrm{q}$ in the absence or presence of a $\mathrm{Cl}^{-}$channel

\begin{tabular}{|c|c|c|c|c|c|c|}
\hline \multirow{2}{*}{$\begin{array}{l}{\left[\mathrm{HCO}_{3}{ }^{-}\right]_{\mathrm{i}}=\left[\mathrm{HCO}_{3}{ }^{-}\right]_{\mathrm{o}}=25} \\
{\left[\mathrm{Na}^{+}\right]_{\mathrm{i}}=10 \mathrm{mM}}\end{array}$} & \multicolumn{2}{|l|}{$V_{l=0}(m V)$} & \multirow{2}{*}{$\begin{array}{l}\Delta \mathrm{E}_{\mathrm{rev}} \\
(\mathrm{mV})\end{array}$} & \multirow{2}{*}{ q $\left(\Delta E_{\text {rev }}\right)$} & \multirow{2}{*}{$\begin{array}{l}\Delta \mathrm{I}_{2} / \Delta \mathrm{I}_{0} \\
\left(\mathrm{~V}_{2}=12 \mathrm{mV}\right)\end{array}$} & \multirow{2}{*}{$\begin{array}{l}q \\
(\Delta l)\end{array}$} \\
\hline & {$\left[\mathrm{Na}^{+}\right]_{\mathrm{o}}=10$} & {$\left[\mathrm{Na}^{+}\right]_{\mathrm{o}}=25$} & & & & \\
\hline$q=2$ & 0 & -23.5 & -23.5 & 2.0 & 1.263 & 2.0 \\
\hline$q=3$ & 0 & -11.75 & -11.75 & 3.0 & 1.595 & 3.0 \\
\hline $\mathrm{q}=2,+\mathrm{G}_{\mathrm{Cl}}$ & -5.1 & -25.3 & -20.2 & 2.17 & 1.263 & 2.0 \\
\hline$q=3,+G_{C l}$ & -12.8 & -18.75 & -5.95 & 4.96 & 1.595 & 3.0 \\
\hline $\mathrm{q}=2,+2 \times \mathrm{G}_{\mathrm{Cl}}$ & -9.2 & -26.9 & -17.7 & 2.33 & 1.263 & 2.0 \\
\hline $\mathrm{q}=3,+2 \times \mathrm{G}_{\mathrm{Cl}}$ & -19.7 & -23.5 & -3.8 & 7.2 & 1.595 & 3.0 \\
\hline
\end{tabular}

$\mathrm{G}_{\mathrm{Cl}}$ represents a $\mathrm{Cl}^{-}$conductance in the conditions of $\left[\mathrm{Cl}^{-}\right]_{\mathrm{i}}=12$ and $\left[\mathrm{Cl}^{-}\right]_{\mathrm{o}}=125 \mathrm{mM}$. Column q $\left(\Delta \mathrm{E}_{\text {rev }}\right)$ represent $\mathrm{q}$ values estimated with $\Delta \mathrm{E}_{\text {rev }}$ method. Column $\mathrm{q}$ $(\Delta \mathrm{l})$ represent q values estimated with $\Delta \mathrm{l}$ method.

These results indicate that the $\Delta \mathrm{E}_{\text {rev }}$ method can significantly bias the estimate depending on the magnitude and electrophysiological properties (e.g. the I-V relationship) of other channels and electrogenic transporters if there are any, while the $\Delta \mathrm{I}$ method gives a more accurate estimate of the transport stoichiometry q.

\section{Discussion}

In this study, we have demonstrated the development and utility of a new method for estimating the transport stoichiometry of electrogenic transport proteins. With this $\Delta \mathrm{I}$ method, one subtracts the currents due to channels and transporters other than the one under study and thereby obtains the stoichiometry of the transporter without the need for a specific inhibitor. Using this method, we showed that the transport stoichiometry of the bicarbonate cotransporter $\mathrm{NBCe} 2-\mathrm{C}$ expressed in HEK-293 cells is $2 \mathrm{HCO}_{3}^{-}: 1 \mathrm{Na}^{+}$that is consistent with the results obtained using the conventional reversal potential method with the inhibitor DIDS. A transport stoichiometry ratio of 2 was also obtained for NBCe1-A with the $\Delta \mathrm{I}$ method that is consistent with the data obtained previously using the conventional reversal potential method with DIDS [25]. In addition, we demonstrated that, with computational simulation, the estimation of $\mathrm{q}$ obtained using the new $\Delta \mathrm{I}$ method was equivalent to that obtained with the conventional $\Delta \mathrm{E}_{\mathrm{rev}}$ methods when an electrogenic NBC transporter was the only transport mechanism in the cell membrane. However, if a chloride channel or a glucose cotransporter SGLT2 was present in the membrane, our simulations showed that the $\Delta \mathrm{E}_{\mathrm{rev}}$ method significantly biased the estimate of the transport stoichiometry q, while the $\Delta \mathrm{I}$ method gave accurate results.

The method proposed in this study is based on Eq. 2 from Heinz [23] that describes the functional relationship between flux of a transporter and the concentrations of transport ions/substrates and the membrane voltage [24]. Unlike the GHK formulation that assumes independence of ion movement across the membrane [13] and does not involve the concept of stoichiometry, Eq. 2 explicitly expresses coupling of $\mathrm{Na}^{+}$and $\mathrm{HCO}_{3}^{-}$ (both are voltage dependent) as a product and the stoichiometry as a power of the concentrations and voltage. Linearity of the current and voltage relation is not a presumption for Eq. 2 nor is it for the GHK equations $[17,18]$. Non-linearity of the I-V curves results from: 1 ) the GHK equation is based on solubility-diffusion theory. In GHK current equation, the current is an exponential function of the voltage. Similarly Eq. 2 shows that flux is an exponential function of voltage; 2) transport mechanisms of membrane channels or transporters represented by the permeability term Ps in GHK equations and $K_{c}$ in Eq. 2 may be voltage dependent. With the conventional $E_{\text {rev }}$ method, if the transporter under study is the only electrogenic pathway, this non-linearity would not be a problem since the current is 0 and at this point, the voltage is the reversal potential under the conditions of the experimental substrate concentrations. However, if there are other channels or electrogenic transporters in the membrane and if a specific inhibitor is not available, $V_{I=0}$ that can be measured is not the reversal potential for the transporter under study, but rather is the voltage at a point on the I-V curve where the net result of the transporter current under study and currents mediated by other transporters and channels is 0 . The alternative $\Delta \mathrm{E}_{\mathrm{rev}}$ method is problematic in that the assumption of reversal potential additivity is inconsistent with non-linearity property of GHK equations and Eq. 2. This is solved by employing the $\Delta \mathrm{I}$ method where the contribution of other channels or transporters can be eliminated without the assumption of $\mathrm{E}_{\mathrm{ver}}$ additivity.

If we assume that an electrogenic NBC transporter has a fixed transport stoichiometry, if the only ions that cross the cell membrane are $\mathrm{Na}^{+}$and $\mathrm{HCO}_{3}{ }^{-}$, from Eq. 2 we have

$$
\begin{aligned}
I=F K_{C} & \left\{\left(\left[N a^{+}\right]_{0} \exp \left(-\frac{F V}{2 R T}\right)\right)^{V_{N a}} \cdot\left(\left[\mathrm{HCO}_{3}{ }^{-}\right]_{0} \exp \left(\frac{F V}{2 R T}\right)\right)^{v_{H C O_{3}}}\right. \\
& \left.-\left(\left[N a^{+}\right]_{i} \exp \left(\frac{F V}{2 R T}\right)\right)^{V_{N a}} \cdot\left(\left[\mathrm{HCO}_{3}{ }^{-}\right]_{i} \exp \left(-\frac{F V}{2 R T}\right)\right)^{v_{H C O_{3}}}\right\}
\end{aligned}
$$

When $\mathrm{I}=0$, we have 
Table 3 Simulation of $\Delta \mathrm{l}$ and $\Delta \mathrm{E}_{\text {rev }}$ methods to estimate $\mathrm{q}$ in conditions similar to rat proximal tubule in the absence or presence of a $\mathrm{Na}^{+} / \mathrm{D}$-glucose cotransporter

\begin{tabular}{|c|c|c|c|c|c|c|}
\hline \multirow{2}{*}{$\begin{array}{l}{\left[\mathrm{HCO}_{3}^{-}\right]_{\mathrm{o}}=24,\left[\mathrm{HCO}_{3}^{-}\right]_{\mathrm{i}}=13.4} \\
{\left[\mathrm{Na}^{+}\right]_{\mathrm{i}}=17 \mathrm{mM}}\end{array}$} & \multicolumn{2}{|l|}{$\underline{V_{\mathrm{l}=0}(\mathrm{mV})}$} & \multirow{2}{*}{$\begin{array}{l}\Delta \mathrm{E}_{\mathrm{rev}} \\
(\mathrm{mVV})\end{array}$} & \multirow{2}{*}{$\begin{array}{l}q \\
\left(\Delta E_{r e v}\right)\end{array}$} & \multirow{2}{*}{$\begin{array}{l}\Delta \mathrm{l}_{2} / \Delta \mathrm{l}_{1} \\
\mathrm{~V}_{2}-\mathrm{V}_{1}=10 \mathrm{mV}\end{array}$} & \multirow{2}{*}{$\begin{array}{l}q \\
(\Delta l)\end{array}$} \\
\hline & {$\left[\mathrm{Na}^{+}\right]_{\mathrm{o}}=150$} & {$\left[\mathrm{Na}^{+}\right]_{\mathrm{o}}=100$} & & & & \\
\hline$q=2$ & -89.6 & -78.75 & 10.85 & 2.0 & 1.205 & 2.0 \\
\hline$q=3$ & -52.6 & -47.2 & 5.4 & 3.0 & 1.45 & 3.0 \\
\hline $\mathrm{q}=2,+\mathrm{Glu}$ & -73.6 & -62.75 & 10.85 & 2.0 & 1.205 & 2.0 \\
\hline$q=3,+$ Glu & 3.2 & 10.2 & 7.0 & 2.55 & 1.45 & 3.0 \\
\hline
\end{tabular}

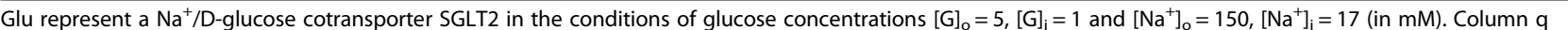
$\left(\Delta \mathrm{E}_{\mathrm{rev}}\right)$ represent $\mathrm{q}$ values estimated with $\Delta \mathrm{E}_{\text {rev }}$ method. Column q $(\Delta \mathrm{l})$ represent q values estimated with $\Delta \mathrm{l}$ method.

$$
\begin{gathered}
\left(\left[\mathrm{Na}^{+}\right]_{o}\right)^{v_{\mathrm{Na}}}\left(\left[\mathrm{HCO}_{3}{ }^{-}\right]_{o}\right)^{v_{\mathrm{HCO}_{3}}} \exp \left(\left(v_{\mathrm{HCO}_{3}}-v_{\mathrm{Na}}\right) \frac{F V_{I=0}}{2 R T}\right) \\
=\left(\left[\mathrm{Na}^{+}\right]_{i}\right)^{v_{\mathrm{Na}}}\left(\left[\mathrm{HCO}_{3}^{-}\right]_{i}\right)^{v_{\mathrm{HCO} O_{3}}} \exp \left(\left(v_{\mathrm{Na}}-v_{\mathrm{HCO}}\right) \frac{F V_{I=0}}{2 R T}\right) \\
\ln \left(\left(\left[\mathrm{Na}^{+}\right]_{o}\right)^{v_{\mathrm{Na}}}\left(\left[\mathrm{HCO}_{3}{ }^{-}\right]_{o}\right)^{v_{\mathrm{HCO}_{3}}}\right)+\left(v_{\mathrm{HCO}_{3}}-v_{\mathrm{Na}}\right) \frac{F V_{I=0}}{2 R T} \\
=\ln \left(\left(\left[\mathrm{Na}^{+}\right]_{i}\right)^{v_{\mathrm{Na}}}\left(\left[\mathrm{HCO}_{3}{ }^{-}\right]_{i}\right)^{v_{\mathrm{HCO}}}\right)+\left(v_{\mathrm{Na}}-v_{\mathrm{HCO}}\right) \frac{F V_{I=0}}{2 R T}
\end{gathered}
$$

Therefore,

$$
\begin{aligned}
V_{I=0} & =\frac{R T}{F\left(v_{\mathrm{HCO}_{3}}-v_{\mathrm{Na}}\right)} \ln \left(\frac{\left(\left[\mathrm{Na}^{+}\right]_{i}\right)^{v_{\mathrm{Na}}}\left(\left[\mathrm{HCO}_{3}^{-}\right]_{i}\right)^{v_{\mathrm{HCO}_{3}}}}{\left(\left[\mathrm{Na}^{+}\right]_{o}\right)^{v_{\mathrm{Na}}}\left(\left[\mathrm{HCO}_{3}^{-}\right]_{o}\right)^{v_{\mathrm{HCO}_{3}}}}\right) \\
& =E_{\mathrm{NBC}}
\end{aligned}
$$

This is essentially Eq. 1 if we take $v_{\mathrm{Na}}=1$ and $\mathrm{q}=v_{\mathrm{HCO} 3} / v_{\mathrm{Na}}$. Starting from here, the widely used delta reversal potential method to estimate stoichiometry $[2,15,16]$ can be easily derived:

When we change $\mathrm{Na}^{+}$concentration in the bath solution from $\left[\mathrm{Na}^{+}\right]_{\mathrm{o} 1}$ to $\left[\mathrm{Na}^{+}\right]_{\mathrm{o} 2}$, we have

$$
V 2_{I=0}=\frac{R T}{F(q-1)} \ln \frac{\left[\mathrm{Na}^{+}\right]_{i}\left(\left[\mathrm{HCO}_{3}^{-}\right]_{i}\right)^{q}}{\left[\mathrm{Na}^{+}\right]_{o 2}\left(\left[\mathrm{HCO}_{3}^{-}\right]_{o}\right)^{q}}
$$

Then, delta reversal potential $\Delta \mathrm{E}_{\mathrm{rev}}$ would be

$$
\begin{aligned}
\Delta E_{\text {rev }}=V 2_{I=0}-V 1_{I=o} & =\frac{R T}{F(q-1)}\left\{\ln \frac{\left[N a^{+}\right]_{i}\left(\left[\mathrm{HCO}_{3}^{-}\right]_{i}\right)^{q}}{\left[\mathrm{Na}^{+}\right]_{o 2}\left(\left[\mathrm{HCO}_{3}^{-}\right]_{o}\right)^{q}}\right. \\
& \left.-\ln \frac{\left[\mathrm{Na}^{+}\right]_{i}\left(\left[\mathrm{HCO}_{3}^{-}\right]_{i}\right)^{q}}{\left[\mathrm{Na}^{+}\right]_{o 1}\left(\left[\mathrm{HCO}_{3}\right]_{o}\right)^{q}}\right\} \\
= & \frac{R T}{F(q-1)} \ln \frac{\left[N a^{+}\right]_{o 1}}{\left[\mathrm{Na}^{+}\right]_{o 2}}
\end{aligned}
$$

From the above operations, we can see that reversal potential method, the $\Delta \mathrm{E}_{\mathrm{rev}}$ method and the $\Delta \mathrm{I}$ method to estimate transport stoichiometry all have the same theoretical foundation (such as Eq. 2 and same assumptions). Moreover, they are equivalent if the electrogenic transporter under investigation is the only conductive process in the membrane.

However, if there are endogenous channels and electrogenic transporters other than the one under study, the relationship of ion activities and transport stoichiometry and reversal potential becomes very complicated as we can see in Eq. 8, Eq. 9 and Eq. 10. Therefore, a method to eliminate the confounding effects of additional transporters and channels on reversal potentials by simple subtraction of $\mathrm{V}_{\mathrm{I}=0}$ is not valid. Our simulation results also indicate that the commonly used $\Delta \mathrm{E}_{\mathrm{rev}}$ method in this instance would not be accurate. The error increases as the currents mediated by other transporters and channels increase (Table 2) relative to the transporter under investigation.

Transport parameters of an electrogenic secondary active transport like $K_{c}$ are affected by many factors. How a given transport process responds theoretically to an electro-chemical gradient depends on the type of the transport kinetic models utilized, e.g. "affinity model", "velocity model" or "mixed model" as described by Heinz [24], and whether the loaded or the unloaded carrier bears an electrical charge. Heinz [23] originally introduced equation 2 and referred to $\mathrm{K}_{\mathrm{c}}$ as a function of mobility and concentrations of the free and loaded carrier, respectively, and hence may vary with the degree of saturation. In our approach, we made two assumptions that are implicitly shared with the $\Delta \mathrm{E}_{\mathrm{rev}}$ method: 1) $\mathrm{K}_{\mathrm{c}}$ is constant in certain voltage range and does not vary when the concentration of the substrate of choice in the study $\left(\left[\mathrm{Na}^{+}\right]_{\mathrm{o}}\right.$ in this study) changes; 2$)$ the sum of currents $\sum_{j} I_{j}$ mediated by other channels and transporters in the membrane as a function of $\mathrm{V}$ does not change when the substrate concentration is altered $[2,15,16]$. Based on these two assumptions the two methods offer benefits such as experimentally straightforward as changing the concentrations of a substrate without the need for specific blockers and share similar limitations. The difference between $\Delta \mathrm{I}$ and $\Delta \mathrm{E}_{\mathrm{rev}}$ method in terms of assumption 2 is that with the $\Delta \mathrm{I}$ method, $\sum_{j} I_{j}$ can be completely eliminated (Eq. 4) if it does not change when the substrate $\left(\left[\mathrm{Na}^{+}\right]_{\mathrm{o}}\right.$ in this study) is 
altered. On the contrary, with the $\Delta \mathrm{E}_{\text {rev }}$ method, as long as $\sum_{j} I_{j}$ is not negligible, the confounding effects of $\sum_{j} I_{j}$ on $\mathrm{V}_{\mathrm{I}=0}$ can not be eliminated and biases the estimation of $\mathrm{q}$ as shown in Figure 6 and Table 2 and Table 3, even if it does not change when the substrate concentration varies.

In practice, ways to circumvent the limitations due to the above assumptions include: 1) using a smaller concentration change of the substrate, as long as it induces a significant delta current; 2) changing the concentrations of a particular substrate with less possibility of involving other electrogenic transporters. For example, in the case of electrogenic $\mathrm{Na}^{+}$-coupled glucose or amino acid transporters, one would choose to change either glucose or amino acids respectively rather than $\mathrm{Na}^{+}$.

In this study, we changed $\left[\mathrm{Na}^{+}\right]_{\mathrm{o}}$ from 10 to $25 \mathrm{mM}$ because: 1) $\mathrm{HCO}_{3}^{-}$partakes in a volatile buffer system that involves $\mathrm{pCO}_{2}$ to keep the $\mathrm{pH}$ constant. $\mathrm{pH}$ would be stable when $\left[\mathrm{HCO}_{3}^{-}\right]_{\mathrm{o}}$ is unaltered; 2) switching $\left[\mathrm{Na}^{+}\right]_{\mathrm{o}}$ from 10 to $25 \mathrm{mM}$ would induce a significant delta current [15] and 3) at these relatively low concentrations, the possibility of transport saturation would be small, therefore variation of $\mathrm{K}_{\mathrm{c}}$ in Eq. 2 and Eq. 3 would be minimized. We assigned $V_{1}=0$ in the above application, therefore in the conditions of $\left[\mathrm{Na}^{+}\right]_{i}=\left[\mathrm{Na}^{+}\right]_{o}$ and $\left[\mathrm{HCO}_{3}^{-}\right]_{i}=\left[\mathrm{HCO}_{3}^{-}\right]_{o}, I_{M}=\sum_{j} I_{j}$ is well defined and it is not close to 0 . In addition, we assigned a $V_{2}$ that is not far from $0(+12 \mathrm{mV}$ in this study), thus possible variation of $\mathrm{K}_{\mathrm{c}}$ under extreme voltages can be minimized.

More detailed kinetic descriptions of the transport rate in order to characterize the entire I-V relationship rely on a detailed understanding of the molecular transport steps [28-30]. This is not necessary for the purposes of our formulation, because we implicitly analyze the portion of the I-V relationship that is close to the $\mathrm{E}_{\text {rev }}$ i.e., $\mathrm{V}_{1}=0$ when $\left[\mathrm{Na}^{+}\right]_{\mathrm{i}}=\left[\mathrm{Na}^{+}\right]_{\mathrm{o}}$ and $\left[\mathrm{HCO}_{3}^{-}\right]_{\mathrm{i}}=\left[\mathrm{HCO}_{3}^{-}\right]_{\mathrm{o}}$.

The accuracy of stoichiometry estimation using wholecell patch-clamp recordings also depends on the accuracy of whole-cell current measurement and the voltages applied to the cell membrane from the patch-clamp amplifier. The drift of the junction potential between the patch pipette solution and the $\mathrm{Ag} / \mathrm{AgCl}$ coated wire that connects to the headstage of the amplifier is a major source of unstable current recording especially when the $\mathrm{Cl}^{-}$concentration in the pipette is low [22]. We used a micro-agar salt bridge of $2 \mathrm{M} \mathrm{KCl}$ in the patch pipette that minimized the junction potential drift and therefore stabilized the whole-cell current measurements [22].

\section{Conclusions}

We developed a new delta current $(\Delta \mathrm{I})$ method for estimating transport stoichiometry of electrogenic transporters based on a simplified model for electrogenic secondary active transport by Heinz (1981). We showed that this model reduces to the conventional reversal potential method when the transporter under study is the only electrogenic transport on the membrane. When there are other electrogenic transport processes such as ion channels or transporters, the $\Delta \mathrm{I}$ method eliminates their contribution in estimation of q. We tested this new $\Delta \mathrm{I}$ methodology in HEK-293 cells expressing the electrogenic SLC4 sodium bicarbonate cotransporters NBCe2-C and NBCe1-A, as well as using computational simulations. Our simulations demonstrated that the $\Delta \mathrm{E}_{\mathrm{rev}}$ method introduces significant error when other channels or electrogenic transporters are present on the membrane with a significant conductance relative to the transporter under study, and that the $\Delta \mathrm{I}$ equation accurately calculates the stoichiometric ratio. Our new $\Delta \mathrm{I}$ method can be readily extended to the analysis of other electrogenic transporters.

\section{Abbreviations}

CMV: Cytomegalovirus; DIDS: 4,4'-Diisothiocyanatostilbene-2,2'-disulfonic acid; EGFP: Enhanced Green Fluorescent Protein; Eq: Equation; Erev: Reversal potential; F: Faraday's constant; GHK: Goldman-Hodgkin-Katz; HEPES: 4-(2Hydroxyethyl)-1-piperazineethanesulfonic acid; I-V: Current-voltage; NBC: Sodium bicarbonate cotransporter; R: Gas constant; SGLT2: Sodiumcoupled glucose transporter 2; T: Absolute temperature; $\Delta \mathrm{E}_{\text {rev }}$ : Delta reversal potential; $\Delta$ l: Delta current.

\section{Competing interests}

The authors declare that they have no competing interests.

\section{Authors' contributions}

XMS, IK conception and design of the research; XMS, and LK performed the experiments; XMS analyzed the data; XMS and IK drafted and revised the manuscript; XMS, LK, and IK approved final version of manuscript.

\section{Acknowledgement}

We thank Dr. Donald D. F. Loo, for helpful discussions and comments on the manuscript.

This work was supported in part by funds from the NIH (R01-DK077162), the Allan Smidt Charitable Fund, the Factor Family Foundation, and the Arvey Foundation (to IK) and R43DA031578-01 (to X. M. S).

\section{Author details}

'Division of Nephrology, Department of Medicine, David Geffen School of Medicine at UCLA, Los Angeles, CA 90095, USA. ${ }^{2}$ Department of Neurobiology, David Geffen School of Medicine at UCLA, Los Angeles, CA 90095, USA. ${ }^{3}$ Brain Research Institute, David Geffen School of Medicine at UCLA, Los Angeles, CA 90095, USA.

Received: 19 August 2014 Accepted: 19 November 2014

Published online: 11 December 2014

\section{References}

1. Kurtz I, Petrasek D, Tatishchev S: Molecular mechanisms of electrogenic sodium bicarbonate cotransport: structural and equilibrium thermodynamic considerations. J Membr Biol 2004, 197(2):77-90.

2. Dong H, Dunn J, Lytton J: Stoichiometry of the Cardiac $\mathrm{Na}^{+} / \mathrm{Ca}^{2+}$ exchanger NCX1.1 measured in transfected HEK cells. Biophys J 2002, 82(4):1943-1952.

3. Bacconi A, Virkki LV, Biber J, Murer H, Forster IC: Renouncing electroneutrality is not free of charge: switching on electrogenicity in a $\mathrm{Na}^{+}$-coupled phosphate cotransporter. Proc Natl Acad Sci U S A 2005, 102(35):12606-12611.

4. Wright EM, Turk E: The sodium/glucose cotransport family SLC5. Pflugers Arch 2004, 447(5):510-518. 
5. Chen NH, Reith ME, Quick MW: Synaptic uptake and beyond: the sodiumand chloride-dependent neurotransmitter transporter family SLC6. Pflugers Arch 2004, 447(5):519-531.

6. Coady MJ, Chen XZ, Lapointe JY: rBAT is an amino acid exchanger with variable stoichiometry. J Membr Biol 1996, 149(1):1-8.

7. Alonso GL, Gonzalez DA, Takara D, Ostuni MA, Sanchez GA: Kinetic analysis of a model of the sarcoplasmic reticulum Ca-ATPase, with variable stoichiometry, which enhances the amount and the rate of $\mathrm{Ca}$ transport. $J$ Theor Biol 2001, 208(3):251-260.

8. Sacher A, Cohen A, Nelson N: Properties of the mammalian and yeast metal-ion transporters DCT1 and Smf1p expressed in Xenopus laevis oocytes. J Exp Biol 2001, 204(Pt 6):1053-1061.

9. Gross E, Kurtz l: Structural determinants and significance of regulation of electrogenic $\mathrm{Na}^{+}-\mathrm{HCO}_{3}^{-}$cotransporter stoichiometry. Am J Physiol Renal Physiol 2002, 283(5):F876-F887.

10. Iwamoto $\mathrm{H}$, Blakely RD, De Felice $\mathrm{L}: \mathrm{Na}^{+}, \mathrm{Cl}^{-}$, and $\mathrm{pH}$ dependence of the human choline transporter ( $\mathrm{hCHT}$ ) in Xenopus oocytes: the proton inactivation hypothesis of hCHT in synaptic vesicles. J Neurosci 2006, 26(39):9851-9859.

11. Ravera S, Virkki LV, Murer H, Forster IC: Deciphering PiT transport kinetics and substrate specificity using electrophysiology and flux measurements. Am J Physiol 2007, 293(2):C606-C620.

12. Coady MJ, Wallendorff B, Bourgeois F, Charron F, Lapointe JY: Establishing a definitive stoichiometry for the $\mathrm{Na}^{+} /$monocarboxylate cotransporter SMCT1. Biophys J 2007, 93(7):2325-2331.

13. Hille B: Ion Channels of Excitable Membranes. Sunderland, Massachusetts: Sinauer Associates; 2001

14. Sassani P, Pushkin A, Gross E, Gomer A, Abuladze N, Dukkipati R, Carpenito $G$, Kurtz I: Functional characterization of NBC4: a new electrogenic sodium-bicarbonate cotransporter. Am J Physiol 2002, 282(2):C408-C416.

15. Yamaguchi $\mathrm{S}$, Ishikawa $\mathrm{T}$ : Electrophysiological characterization of native $\mathrm{Na}^{+}-\mathrm{HCO}_{3}^{-}$cotransporter current in bovine parotid acinar cells. J Physiol 2005, 568(Pt 1):181-197.

16. Owe SG, Marcaggi $P$, Attwell D: The ionic stoichiometry of the GLAST glutamate transporter in salamander retinal glia. J Physiol 2006, 577(Pt 2):591-599.

17. Goldman DE: Potential, Impedance, and Rectification in Membranes. J Gen Physiol 1943, 27(1):37-60.

18. Hodgkin AL, Katz B: The effect of sodium ions on the electrical activity of giant axon of the squid. J Physiol 1949, 108(1):37-77.

19. Kurtz I: SLC4 Sodium-driven bicarbonate transporters. In Seldin and Giebisch's The Kidney: Physiology and Pathophysiology. 5th edition. Edited by Alpern RJ, Moe OW, Caplan M. Amsterdam, Boston: Elsevier/Academic Press; 2013:1837-1860

20. Kao L, Kurtz LM, Shao X, Papadopoulos MC, Liu L, Bok D, Nusinowitz S, Chen B, Stella SL, Andre M, Weinreb J, Luong SS, Piri N, Kwong JMK, Newman D, Kurtz I: Severe neurologic impairment in mice with targeted disruption of the electrogenic sodium bicarbonate cotransporter NBCe2 (Slc4a5 gene). J Biol Chem 2011, 286(37):32563-32574.

21. Millar ID, Brown PD: NBCe2 exhibits a $3 \mathrm{HCO}_{3}^{-}: 1 \mathrm{Na}+$ stoichiometry in mouse choroid plexus epithelial cells. Biochem Biophys Res Commun 2008, 373(4):550-554.

22. Shao XM, Feldman JL: Micro-agar salt bridge in patch-clamp electrode holder stabilizes electrode potentials. J Neurosci Methods 2007, 159(1):108-115.

23. Heinz E: Membrane Potential in Secondary Active Transport. In Electrical Potentials in Biological Membrane Transport. Berlin: Springer-Verlag; 1981:46-50.

24. Geck $P$, Heinz E: Coupling in secondary transport. Effect of electrical potentials on the kinetics of ion linked co-transport. Biochim Biophys Acta 1976, 443(1):49-63.

25. Zhu Q, Shao XM, Kao L, Azimov R, Weinstein AM, Newman D, Liu W, Kurtz I: Missense mutation T485S alters NBCe1-A electrogenicity causing proximal renal tubular acidosis. Am J Physio/ 2013, 305(4):C392-C405.

26. Yoshitomi K, Burckhardt BC, Fromter E: Rheogenic sodium-bicarbonate cotransport in the peritubular cell membrane of rat renal proximal tubule. Pflugers Arch 1985, 405(4):360-366

27. Hummel CS, Lu C, Loo DD, Hirayama BA, Voss AA, Wright EM: Glucose transport by human renal $\mathrm{Na}^{+} / \mathrm{D}$-glucose cotransporters SGLT1 and SGLT2. Am J Physiol 2011, 300(1):C14-C21.
28. Sanders D: Generalized kinetic analysis of ion-driven cotransport systems: II. Random ligand binding as a simple explanation for non-michaelian kinetics. J Membr Biol 1986, 90(1):67-87.

29. Parent L, Supplisson S, Loo DD, Wright EM: Electrogenic properties of the cloned $\mathrm{Na}^{+}$/glucose cotransporter: II. A transport model under nonrapid equilibrium conditions. J Membr Biol 1992, 125(1):63-79.

30. Gross E, Hopfer U: Voltage and cosubstrate dependence of the $\mathrm{Na}-\mathrm{HCO} 3$ cotransporter kinetics in renal proximal tubule cells. Biophys J 1998, 75(2):810-824

doi:10.1186/s13628-014-0014-2

Cite this article as: Shao et al:: A novel delta current method for

transport stoichiometry estimation. BMC Biophysics 2014 7:14

\section{Submit your next manuscript to BioMed Central and take full advantage of:}

- Convenient online submission

- Thorough peer review

- No space constraints or color figure charges

- Immediate publication on acceptance

- Inclusion in PubMed, CAS, Scopus and Google Scholar

- Research which is freely available for redistribution 